\title{
Evaluación del efecto de tratamientos de desinfección con hipoclorito de sodio sobre segmentos nodales de Guadua angustifolia Kunth para el establecimiento del cultivo in vitro
}

\section{Evaluation of the effect of disinfection treatments with sodium hypochlorite over nodal segments present in Guadua angustifolia Kunth for the establishment of the in vitro culture.}

\author{
Avaliação do efeito de tratamentos de desinfecção com \\ hipoclorito de sódio em segmentos nodais de Guadua \\ angustifolia Kunth para o estabelecimento de cultivo in vitro
}

Lorena Alexandra Ramírez Correa ${ }^{1}$, Jairo Enrique Granados Moreno² \& Nidia Elizabeth Carreño González ${ }^{3}$

'Licenciada en Biología y Educación Ambiental, Especialista en Biotecnología Agraria. ${ }^{2}$ Licenciado en Química, Magister en Docencia de la Química. ${ }^{3}$ Médica Veterinaria Zootecnista, Especialista en

Nutrición Animal Sostenible, Magister en Ciencias Agropecuarias

${ }^{1}$ Corporación Autónoma Regional del Quindío. Centro Nacional para el Estudio del Bambú - Guadua. Calle 19 Norte N 19-55. Armenia, Quindío. Colombia. ${ }^{2}{ }^{3}$ Escuela de Ciencias Agrícolas, Pecuarias y del Medio Ambiente -ECAPMA. Universidad Nacional Abierta y a Distancia -UNAD. Bogotá. Colombia

Iorealexa0221@yahoo.es, jairo.granados@unad.edu.co,nidia.carreno@unad.edu.co

\section{Resumen}

El establecimiento del cultivo in vitro de segmentos nodales de Guadua angustifolia presenta como principal inconveniente la contaminación por microorganismos, causando pérdidas biológicas y económicas. Esta investigación fue desarrollada en el Centro Nacional para el Estudio del Bambú-Guadua, en Córdoba, Quindío y financiada por la Corporación Autónoma Regional del Quindío (C.R.Q). Se evaluaron seis tratamientos para la desinfección de los explantes de guadua con hipoclorito de sodio ( $\mathrm{NaClO}$ ) en concentraciones del $2 \%$ y $3 \%$, cada uno en tiempos de aplicación de 5, 10 y 15 minutos, posteriormente los explantes fueron sembrados en el medio de cultivo Murashige y Skoog, suplementado con 6-BAP a razón de $3 \mathrm{mg} \mathrm{L}^{-1}$.
También se valoró el porcentaje de brotación. El mejor resultado de desinfección y de brotación se obtuvo con el $\mathrm{NaClO}$ al $2 \%$ durante 15 minutos.

Palabras clave: Guadua angustifolia, explante, cultivo in vitro, hipoclorito de sodio, desinfección, brotación.

\section{Abstract}

The establishment of the in vitro culture of Guadua angustifolia nodal segments presents as the main problem the contamination by microorganisms, causing biological and economic losses. This research was developed at the National Center for the Study of the bamboo-Guadua bamboo, in municipality of Cordoba, Quindio and it was 
financed by the Regional Autonomous Corporation of the Quindio (C. R. Q). Six treatments were evaluated for the disinfection of the explants of guadua bamboo with sodium hypochlorite $(\mathrm{NaClO})$ in concentrations of $2 \%$ and $3 \%$, each one of them in time of application of 5,10 , and 15 minutes, the explants were planted in the culture medium Murashige and Skoog medium supplemented with 6-BAP at a rate of $3 \mathrm{mg} \mathrm{L}^{-1}$. The percentage of sprouting was also evaluated. The best result of disinfection and budding was obtained with the $\mathrm{NaClO}$ to $2 \%$ for 15 minutes.

Key-words: Guadua angustifolia, explant, in vitro culture, sodium hypochlorite, disinfection, sprouting.

\section{Resumo:}

O estabelecimento de cultivo in vitro de segmentos nodais de Guadua angustifolia tem como principal desvantagem a contaminação por microorganismos, causando perdas biológicas e econômicas. Este trabalho foi desenvolvido no Centro Nacional para o Estudo da Bamboo-Guadua em Córdoba, Quindío e financiado pela Corporação Autônoma Regional de Quindío (CRQ). Foram avaliados seis tratamentos para desinfecção de explantes de bambu com hipoclorito de sódio ( $\mathrm{NaClO}$ ) nas concentrações de $2 \%$ e 3\%, cada épocas de aplicação de 5, 10 e 15 minutos, após os explantes foram plantadas no meio de cultura Murashige e Skoog suplementado com BAP-6 a uma taxa de $3 \mathrm{mg} \mathrm{L}^{-1}$. também foi avaliada a porcentagem de brotação $O$ melhor resultado de desinfecção e brotação foi obtido com $2 \%$ de hipoclorito de sódio durante 15 minutos.

Palavras-chave: Guadua angustifolia, explante, cultura in vitro, hipoclorito de sódio desinfecção, brotação.

\section{Introducción}

La guadua es una especie forestal que puede brindar múltiples beneficios ambientales, económicos, sociales y culturales; es usada en la construcción y en la elaboración de artesanías. En ecosistemas forestales, la guadua hace grandes aportes de biomasa, contribuye a enriquecer y mejorar la textura y estructura del suelo, proporciona un mayor anclaje evitando la erosión, y ayuda a la regulación de los caudales (Giraldo \& Sabogal, 2007).

Se utiliza la micropropagación como la principal biotécnica aplicada a varias especies de bambú (Cruz et al., 2007) y es necesaria la adición de hormonas y la adopción de procedimientos de asepsia para mantener los cultivos libres de contaminación microbiana (Roca \& Mroginski, 1991). En la fase de establecimiento de especies leñosas, el explante inicial constituye la principal fuente de contaminación, debido a las características anatómicas propias de las especies (Cruz et al., 2007)

Existen pocas investigaciones del cultivo in vitro de Guadua angustifolia que reportan diferentes tratamientos de desinfección para segmentos nodales, como utilización de métodos de desinfección con hipoclorito de sodio ( $\mathrm{NaClO}$ ) al $2 \%$ por 5,10 y 15 minutos y la repetición de estos mismos tratamientos a las 24 horas, demostrando que la doble desinfección con una concentración del $2 \%$ de $\mathrm{NaOCl}$ durante 5 minutos es la más adecuada para el establecimiento in vitro de explantes primarios (Borges, Ros, Castellanis \& Velásquez, 2004). Igualmente se ha realizado la desinfección de los segmentos nodales con hipoclorito de sodio al $1 \%$ durante 5 minutos. (Freire et al., 2011)

Por otra parte, se ha empleado el bicloruro de mercurio $(\mathrm{HgCl} 2)$ como agente desinfectante al $0.3 \%$ durante 5 y 10 minutos y el hipoclorito de sodio al $2 \%$ durante 10, 15 y 20 minutos en la desinfección de las yemas nodales (Lárraga, 2011) obteniendo el mejor resultado con bicloruro de mercurio al $0.3 \%$ durante 10 minutos (Marulanda, Gutiérrez, Uribe \& Márquez, 2005). También se ha realizado la desinfección de yemas axilares con una combinación de fungicidas y bactericidas y posterior sumergimiento de los explantes en hipoclorito de sodio al 1.5\% durante 10 minutos (Jiménez, Castillo, Tavares, Guevara \& Montie, 2006). 
Dado que el principal inconveniente en la micropopagación de Guadua angustifolia es la contaminación por bacterias, causando pérdidas biológicas y económicas (Leifert, Ritchie \& Waities, 1991), tanto en la micropropagación comercial, como en los trabajos de investigación (Fonturbel, 2001) y que uno de los agentes desinfectantes más empleados en la micropropagación vegetal, por su bajo costo, fácil adquisición y menor efecto fitotóxico sobre los tejidos es el hipoclorito de sodio, se plantea su uso en concentraciones del $2 \%$ y $3 \%$, en tiempos de exposición de 5, 10 y 15 minutos, para desinfección de segmentos nodales de Guadua angustifolia determinando las condiciones para el establecimiento in vitro de esta especie.

\section{Materiales y métodos}

\section{Ubicación}

Esta investigación se realizó en el Centro Nacional para el Estudio del bambú - Guadua (CNBG), en el municipio de Córdoba, departamento de

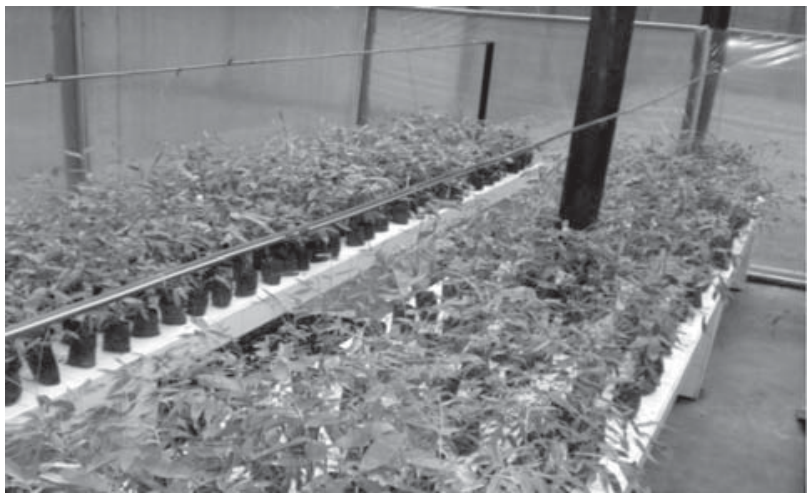

Figura 1. Plantas madre de G. angustifolia en condiciones de invernadero

Fuente: Ramirez, L. (2009).
Quindío, Colombia, en donde se desarrolla su micropropagación. El CNBG se encuentra localizado a $22 \mathrm{~km}$ de la ciudad de Armenia, a $1.176 \mathrm{msnm}$, temperatura promedio de $25^{\circ} \mathrm{C}$, una precipitación anual de $2.242 \mathrm{~mm}$ año-1; Brillo solar 1.800 horas año-1 y una humedad relativa del $85 \%$.

\section{Selección y siembra de los segmentos noda- les de Guadua angustifolia}

Las plantas madre se mantuvieron bajo condiciones de invernadero (Figura 1) y bajo excelentes condiciones fitosanitarias, a una temperatura promedio de $28^{\circ} \mathrm{C}$. Fueron regadas dos veces a la semana con agua destilada, y fumigadas con productos bacteriostáticos y fungistáticos, con el fin de disminuir la contaminación en el cultivo in vitro por hongos y bacterias. Así mismo, fueron podadas con regularidad para estimular la acción de las auxinas en la brotación de las yemas usadas como explantes. Los segmentos nodales fueron tomados de varas largas sin ramificar (Figura 2), y cortados con tijeras podadoras, las cuales se desinfectaron con alcohol etílico al $70 \%$.

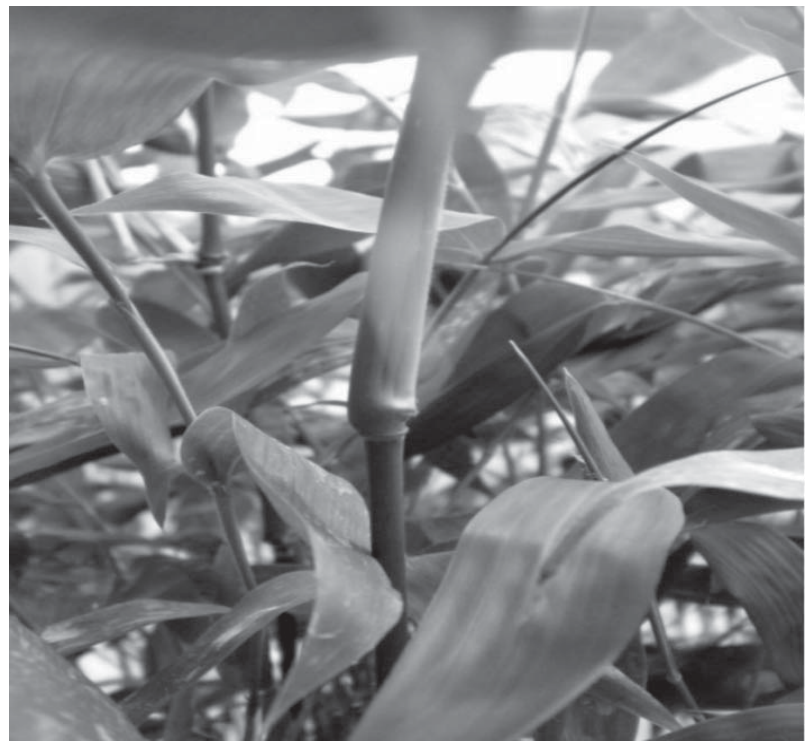

Figura 2. Segmento nodal en planta madre de $G$. angustifolia

Fuente: Ramirez, L. (2009). 
Los explantes fueron sometidos a un pre-lavado en $1 \mathrm{~L}$ de agua destilada estéril con jabón líquido $(5 \mathrm{~mL})$, yodo quirúrgico (10 mL), L-Cysteína $(5 \mathrm{mg})$ y Tween 20 (1 mL) por 15 minutos, con agitación constante y posteriormente se lavaron tres veces con agua destilada estéril.

\section{Tratamientos de desinfección de los explantes}

Después del tratamiento de predesinfección de los explantes, en cabina de flujo laminar, fueron desinfectados de acuerdo a los tratamientos especificados en la Tabla 1.

Tabla 1. Tratamientos de desinfección aplicados a los segmentos nodales de Guadua angustifolia

\begin{tabular}{lcccccc}
\hline $\begin{array}{c}\text { Trata- } \\
\text { miento }\end{array}$ & $\begin{array}{c}\text { Cantidad de } \\
\text { Explantes } \\
\text { (und) }\end{array}$ & Desinfección & $\begin{array}{c}\text { Tiempo de } \\
\text { Exposición } \\
\text { (min) }\end{array}$ & Desinfección & $\begin{array}{c}\text { Concen } \\
\text { Tración }\end{array}$ & $\begin{array}{c}\text { Tiempo de } \\
\text { Exposición } \\
\text { (min) }\end{array}$ \\
\hline $\mathbf{1}$ & 100 & Etanol & 2 & $\mathrm{NaClO}$ & $2 \%$ & 5 \\
$\mathbf{2}$ & 100 & Etanol & 2 & $\mathrm{NaClO}$ & $2 \%$ & 10 \\
$\mathbf{3}$ & 100 & Etanol & 2 & $\mathrm{NaClO}$ & $2 \%$ & 15 \\
$\mathbf{4}$ & 100 & Etanol & 2 & $\mathrm{NaClO}$ & $3 \%$ & 5 \\
$\mathbf{5}$ & 100 & Etanol & 2 & $\mathrm{NaClO}$ & $3 \%$ & 10 \\
$\mathbf{6}$ & 100 & Etanol & 2 & $\mathrm{NaClO}$ & $3 \%$ & 15 \\
\hline
\end{tabular}

Como se aprecia en la Tabla 1, se utilizaron dos concentraciones de hipoclorito de sodio, para obtener seis tratamientos así: $\mathrm{NaClO}$ al $2 \%$ con direferentes tiempos de exposición (5, 10 y 15 minutos), y NaClO al 3\% con direferentes tiempos de exposición (5, 10 y 15 minutos).

\section{Siembra de los explantes}

Se sembraron 600 explantes de Guadua angustifolia en condiciones in vitro. Una vez los explantes fueron desinfectados se sembraron en el medio de cultivo Murashige y Skoog (MS) (Tabla 2), con pH entre 5,7-6.0, suplementado con la citoquinina BAP (citoquinina sintética 6-bencilaminopurina) a razón de $3.0 \mathrm{mg} \mathrm{L}^{-1}$ previamente esterilizado en autoclave a $120 \stackrel{\circ}{C}$ y 15 psi de presión durante 30 minutos.

Tabla 2. Composición del medio MS

\begin{tabular}{lcc}
\hline & Componentes & Cantidad \\
$\mathrm{NH}_{4} \mathrm{NO}_{3}$ & 1650 \\
$\mathrm{KNO}_{3}$ & 1900 \\
$\mathrm{KH}_{2} \mathrm{PO}_{4}$ & 170 \\
$\mathrm{CaCl}_{2} \cdot 2 \mathrm{H}_{2} \mathrm{O}$ & 440 \\
$\mathrm{MgSO}_{4} \cdot 7 \mathrm{H}_{2} \mathrm{O}$ & 370 \\
$\mathrm{KI}$ & 0.83 \\
$\mathrm{H}_{3} \mathrm{BO}_{3}$ & 6.2 \\
$\mathrm{MnSO}_{4} \cdot 4 \mathrm{H}_{2} \mathrm{O}$ & 22.3 \\
$\mathrm{ZnSO}_{4} \cdot 7 \mathrm{H}_{2} \mathrm{O}$ & 8.6 \\
$\mathrm{NaMoO}_{4} \cdot 2 \mathrm{H}_{2} \mathrm{O}$ & 0.25 \\
$\mathrm{CuSO}_{4} \cdot 5 \mathrm{H}_{2} \mathrm{O}$ & 0.025 \\
$\mathrm{FeSO}_{4} \cdot 7 \mathrm{H}_{2} \mathrm{O}$ & 27.8 \\
$\mathrm{Na}_{2} \mathrm{EDTA}_{2} \cdot 7 \mathrm{H}_{2} \mathrm{O}$ & 37.3 \\
$\mathrm{CoCl}$ & $6 \mathrm{H}_{2} \mathrm{O}$ & 0.025 \\
$\mathrm{Glicina}$ & 2 \\
Tiamina-HCl & 0.1 \\
Piridoxina-HCl & 0.5 \\
Ácido nicotínico & 0.5 \\
Mioinositol & 100 \\
Sacarosa & 30 \\
\hline
\end{tabular}

Fuente: Roca \& Mroginski (1993) 


\section{Incubación y evaluación de los explantes}

Los explantes sembrados se llevaron a cámara de crecimiento donde permanecieron bajo condiciones de oscuridad por 20 días a una temperatura de $28^{\circ} \mathrm{C}$ esto con el fin de evitar la oxidación de los segmentos nodales. Cuando los explantes mostraron señales de brotación se mantuvieron en oscuridad por 4 días más y luego fueron incubados con un fotoperíodo de 12 horas luz.

Los segmentos nodales contaminados fueron retirados de la sala de incubación y posteriormente esterilizados en autoclave. Los demás explantes se mantuvieron en observación para verificar su brotación y así continuar con la fase de establecimiento.

\section{Análisis estadístico}

Se aplicó un análisis estadístico descriptivo de las variables analizadas en cuanto a contaminación, brotación y segmentos nodales no promisorios, para las concentraciones aplicadas de hipoclorito de sodio al $2 \%$ y $3 \%$, en los 3 tiempos de aplicación de 5 minutos, 10 minutos y 15 minutos.

\section{Variables evaluadas}

Las variables dependientes evaluadas en esta investigación, se muestran en la Tabla 3

Tabla 3. Variables evaluadas en el experimento

\begin{tabular}{lcl}
\hline \multicolumn{1}{c}{ Variables evaluadas } & Unidad de medición & Técnica utilizada \\
Contaminación bacteriana & Unidades & Observación directa \\
Brotación & Unidades & Observación directa \\
Plántulas no promisorias & Unidades & Observación directa \\
\hline
\end{tabular}

\section{Resultados y discusión}

\section{Evaluación de los tratamientos de desinfección}

Con base en los tratamientos de desinfección, a los cuales fueron sometidos los explantes de $G$. angustifolia, se obtuvieron los siguientes resultados:

\section{Evaluación de la contaminación}

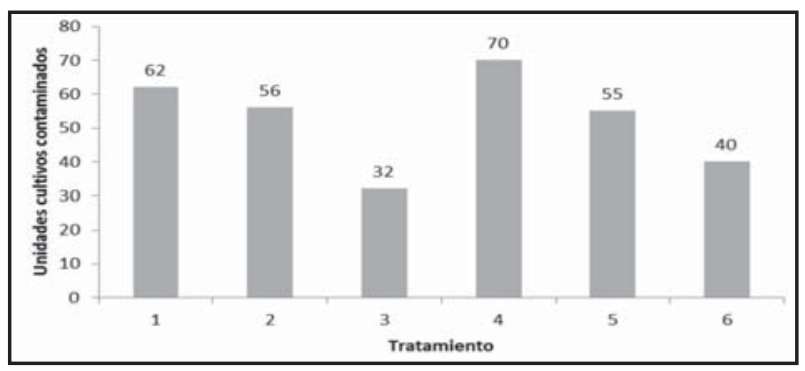

Figura 3. Contaminación de los segmentos nodales de G. angustifolia por tratamientos de desinfección aplicados
En la Figura 3, se observa que el tratamiento con mejor actividad de desinfección sobre los explantes fue el tratamiento 3 , con la aplicación del $\mathrm{NaClO}$ al $2 \%$ durante 15 minutos, con 32 cultivos contaminados. El tratamiento que reportó mayor contaminación fue el 4 con la aplicación del $\mathrm{NaClO}$ al $3 \%$ por 5 minutos. Al calcular el promedio entre los diferentes tratamientos y tiempos de exposición, se encontró un índice de contaminación alto con un promedio de 50 unidades de cultivos contaminados para el tratamiento con $\mathrm{NaClO}$ al $2 \%$ y de 55 unidades de cultivos contaminados para el tratamiento con el $\mathrm{NaClO}$ al 3\%, lo cual concuerda con lo encontrado por Ramírez et al. (2009), Jiménez et al. (2006), Marulanda et al. (2005) y Borges et al. (2004), quienes reportan una contaminación entre el $20 \%$ y $86 \%$ en los cultivos in vitro de esta especie. Estos resultados se pueden explicar porque el hipoclorito de sodio contribuye a la desinfección de los explantes ya que el mecanismo de acción del compuesto permite el 
daño de la membrana celular de las bacterias, originando la lisis del microorganismo (Sánchez \& Sáenz, 2005). Más adelante se observará su acción de acuerdo a la concentración del $\mathrm{Na}$ $\mathrm{CIO}$, los tiempos de aplicación y el tiempo total de evaluación en el experimento. Sin embargo, sigue siendo alto el porcentaje de contaminación de los segmentos nodales de Guadua angustifolia, debido a la complejidad de la especie forestal leñosa.

\section{Evaluación de la brotación}

Con relación a la brotación de los segmentos nodales, en la Figura 4 se aprecia que el tratamiento con mayor número de segmentos nodales brotados fue el tratamiento 3, con aplicación del $\mathrm{NaClO}$ al 2\% durante 15 minutos, produciendo 15 brotaciones de los explantes de $G$. angustifolia. El tratamiento que reportó menor brotación fue el tratamiento 4 con aplicación del $\mathrm{NaClO}$ al 3\% por 5 minutos.

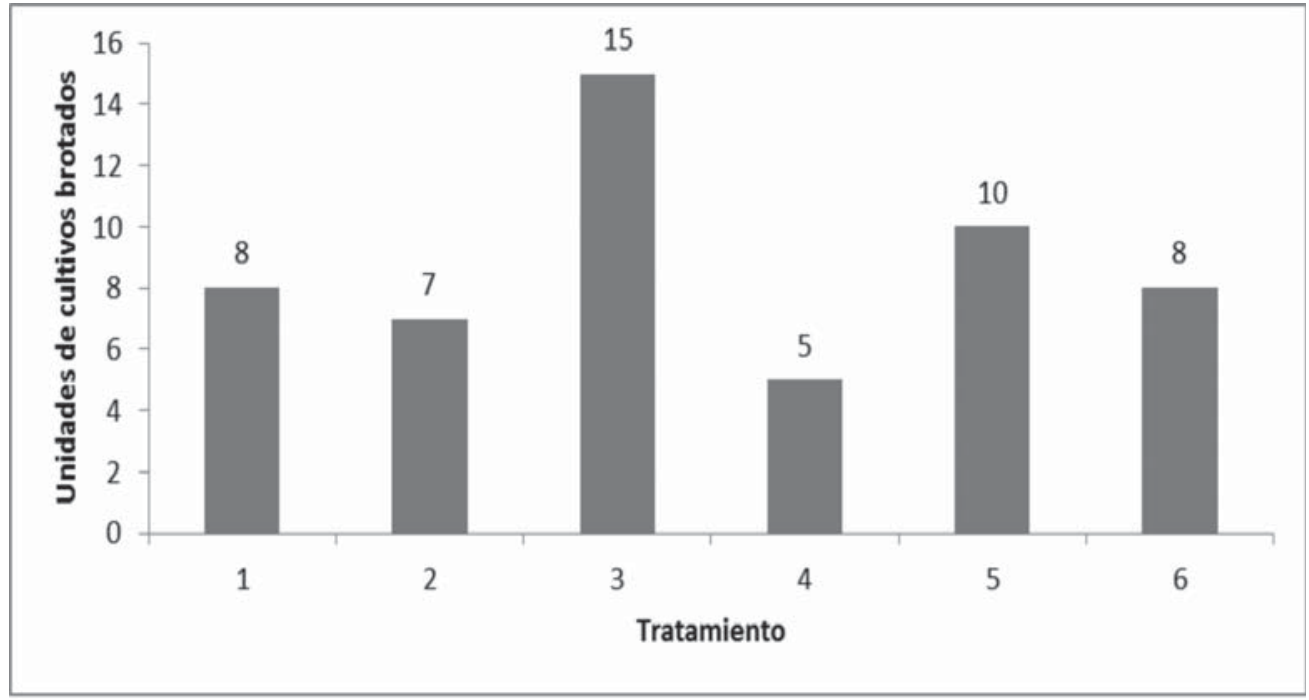

Figura 4. Brotación de los segmentos nodales de G. angustifolia por tratamientos de desinfección aplicados
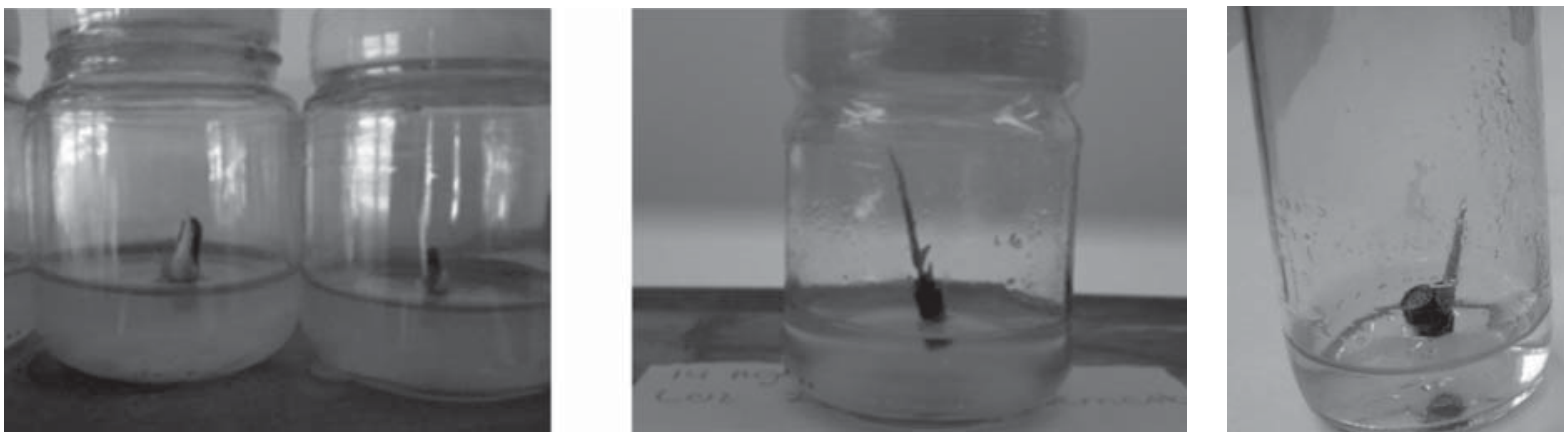

Figura 5 . Segmentos nodales de Guadua angustifolia en brotación Fuente: Ramirez, L. (2009)

\section{Evaluación de segmentos nodales no promisorios}

En cuanto a los resultados en el número de segmentos nodales no promisorios, la Figura 4, indica que el tratamiento con el mayor número de segmentos nodales no promisorios fue el tratamiento 3 , con aplicación del $\mathrm{NaClO}$ al $2 \%$ durante 15 minutos. El tratamiento que reportó menor cantidad de explantes no promisorios fue el tratamiento 4 con $\mathrm{NaClO}$ al $3 \%$ por 5 minutos. Con relación a esta variable no se reportan datos en la consulta bibliográfica. 


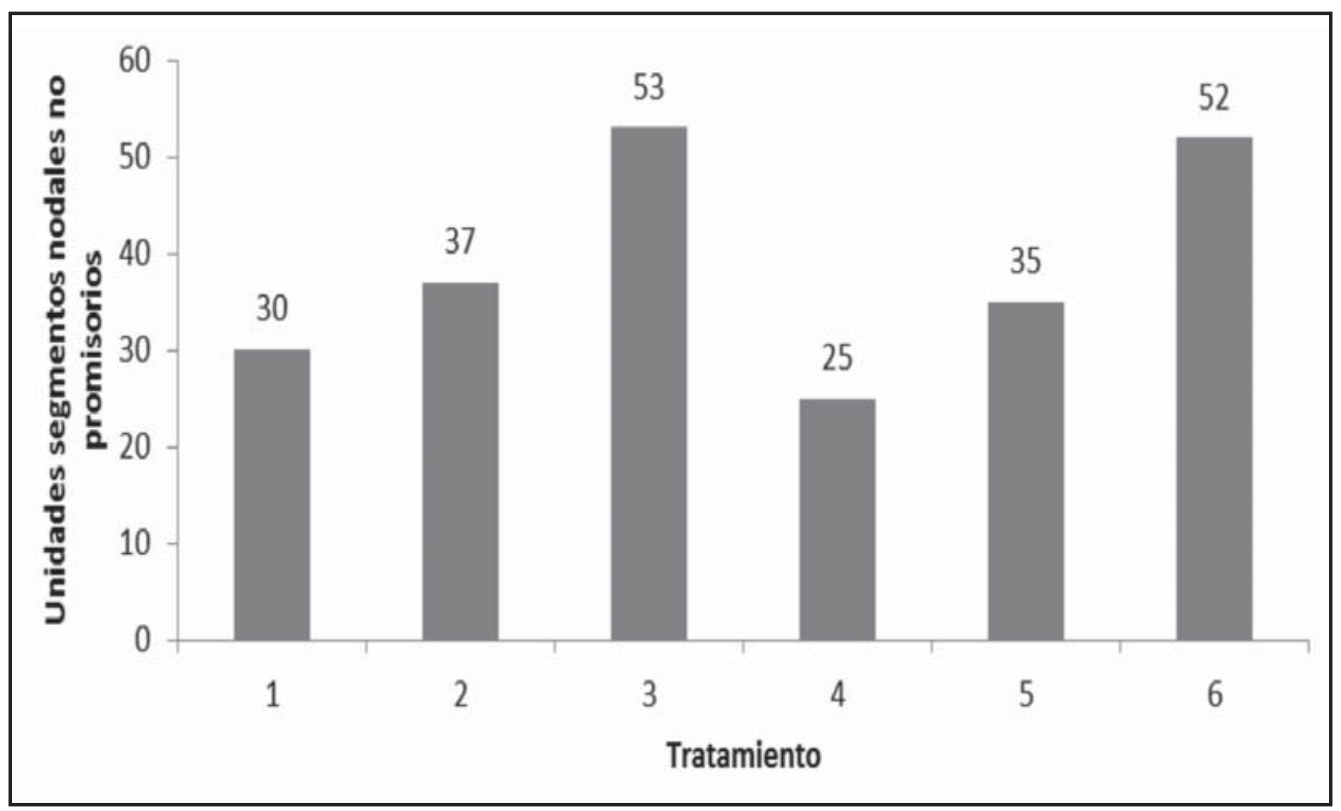

Figura 6. Segmentos nodales no promisorios de G. angustifolia por tratamientos de desinfección aplicados

\section{Análisis del tratamiento de $\mathrm{NaClO} 2 \%$ con relación al tiempo de exposición de los explantes}

Para observar el efecto desinfectante de los tratamientos, así como la brotación y segmentos nodales no promisorios, se realizó el análisis del comportamiento de los explantes en el tratamiento $\mathrm{NaClO} 2 \%$ de acuerdo con el tiempo de exposición de 5, 10 y 15 minutos durante los días posteriores a la siembra. A continuación se presentan los resultados encontrados:

\section{Efectos de aplicación de $\mathrm{NaClO}$ 2\% durante 5 minutos}

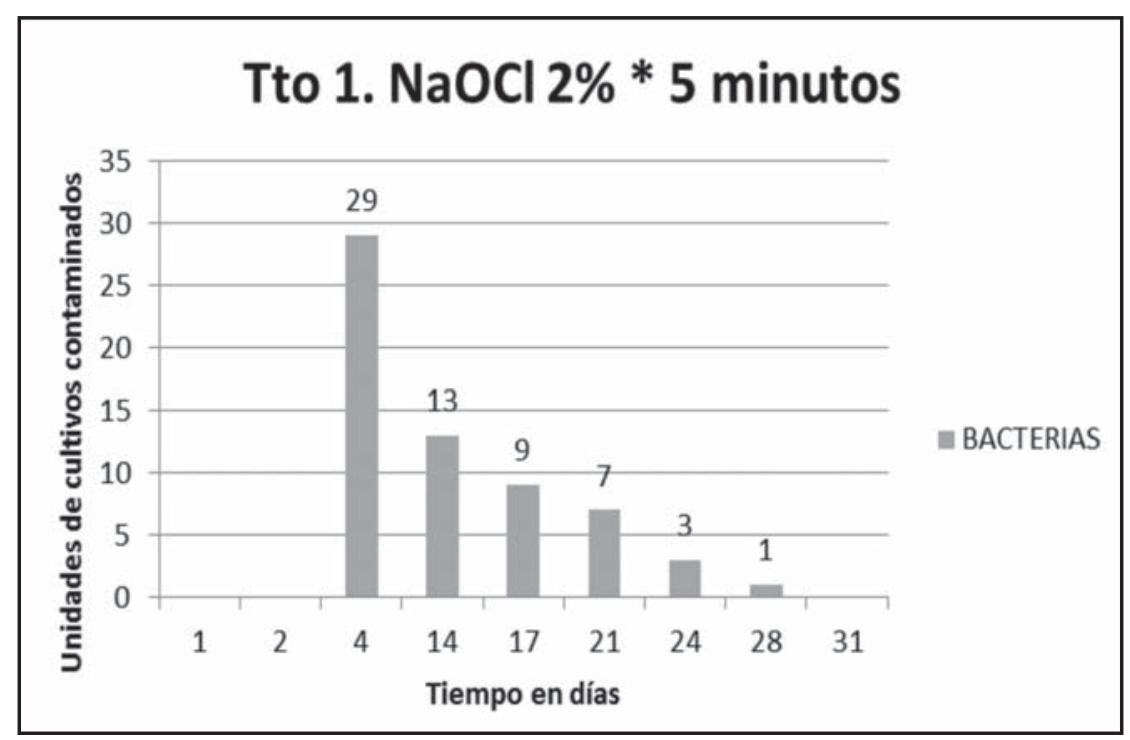

Figura 7. Análisis comparativo entre el protocolo de desinfección y la variable contaminación con el tratamiento $\mathrm{NaClO} 2 \%$ por 5 minutos 
En la aplicación del $\mathrm{NaClO}$ al $2 \%$ durante 5 minutos (Figura 7), la mayor contaminación se presenta a partir del cuarto día de la siembra in vitro en 29 de los segmentos nodales y disminuye proporcionalmente con el tiempo. Este resultado concuerda con lo reportado por Ramírez, Urdaneta \& León, (2002), quienes obtuvieron la mayor contaminación durante los primeros 7 días a partir de la siembra in vitro; y concuerda con lo reportado por Borges et al., (2004) quienes obtuvieron el $20 \%$ de contaminación con la aplicación de $\mathrm{NaClO}$ al $2 \%$ durante 5 minutos.

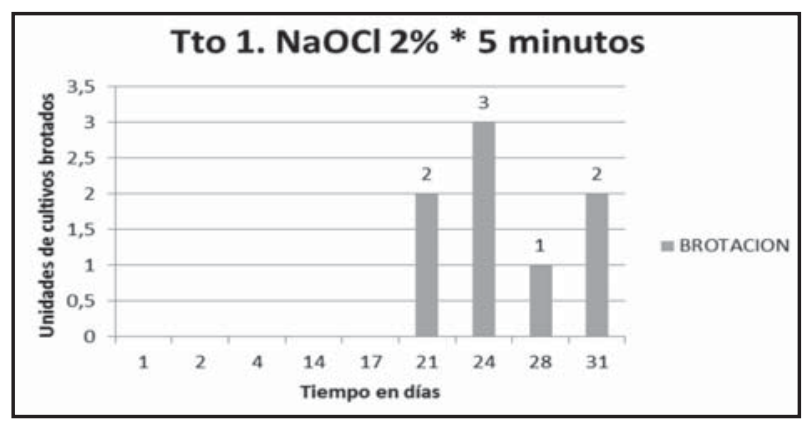

Figura 8 . Análisis comparativo entre el protocolo de desinfección y la variable brotación con el tratamiento $\mathrm{NaClO} 2 \%$ por 5 minutos

En cuanto a la variable brotación (Figura 8), se encontró que a mayor tiempo de exposición al $\mathrm{NaClO}$ al $2 \%$, hay mayor generación de brotes, obteniendo una brotación de 5 explantes entre los días 21 y 24, una sola brotación el día 28 y un leve incremento de 2 cultivos brotados el día 31 . El total de segmentos nodales brotados en este tratamiento fue de 8 .

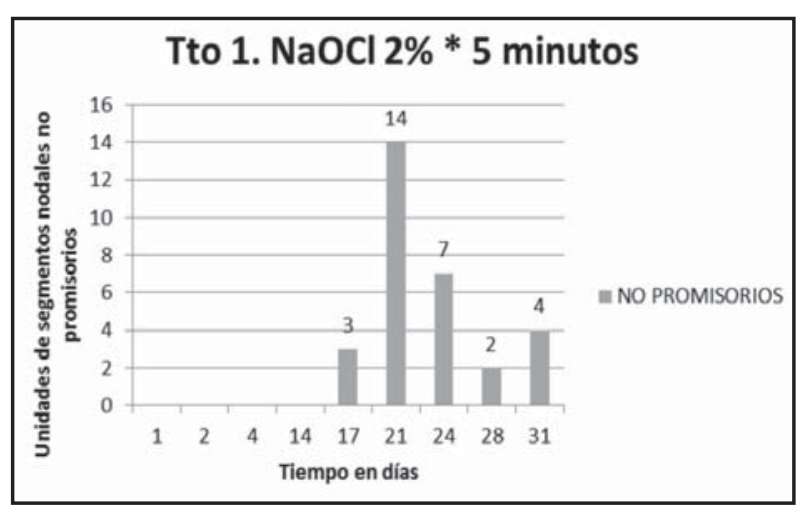

Figura 9 . Análisis comparativo entre el protocolo de desinfección y la variable segmentos nodales no promisorios con el tratamiento $\mathrm{NaClO} 2 \%$ por 5 minutos
Para los explantes no promisorios (Figura 9), se observa un crecimiento exponencial desde el día 17 al 21, siendo este último día el más significativo con 14 cultivos no promisorios.

\section{Efectos de aplicación de $\mathrm{NaClO}$ 2\% durante 10 minutos}

En la aplicación del $\mathrm{NaClO}$ al 2\% durante 10 minutos (Figura 10), la mayor contaminación se presenta en 24 de los segmentos nodales, en el séptimo día a partir de la siembra in vitro y disminuye proporcionalmente con el tiempo. Este resultado concuerda con lo reportado por Ramírez et al., (2002), quienes obtuvieron la mayor contaminación entre los días 2 y 7 a partir de la siembra in vitro.

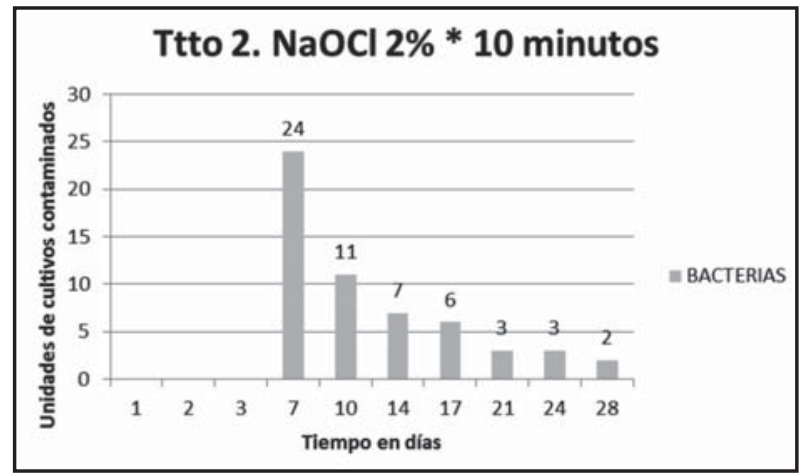

Figura 10. Análisis comparativo entre el protocolo de desinfección y la variable contaminación con el tratamiento $\mathrm{NaClO} 2 \%$ por 10 minutos

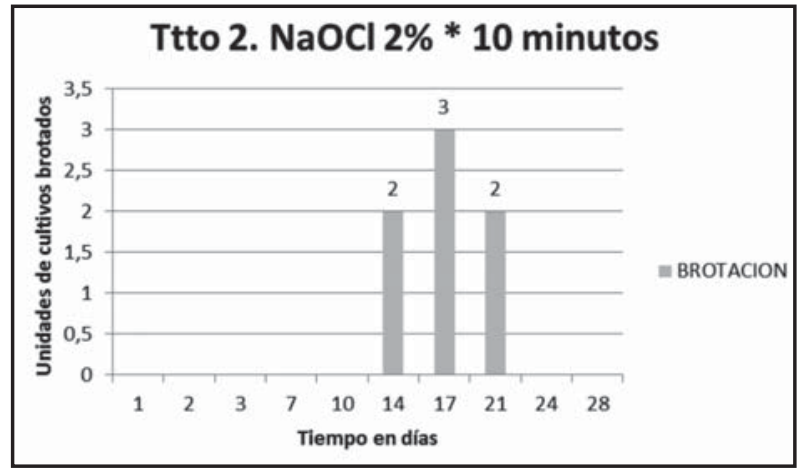

Figura 11 Análisis comparativo entre el protocolo de desinfección y la variable brotación con el tratamiento $\mathrm{NaClO} 2 \%$ por 10 minutos 
En cuanto a la variable brotación (Figura 11), se aprecia que a mayor tiempo se incrementa la presencia de brotación, obteniendo en total 7 cultivos a partir del día 14 al 21.

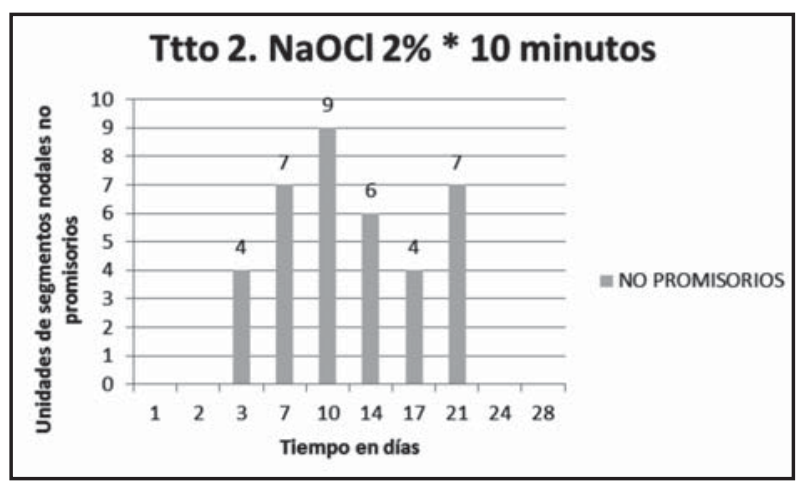

Figura 12. Análisis comparativo entre el protocolo de desinfección y la variable segmentos nodales no promisorios con el tratamiento $\mathrm{NaClO} 2 \%$ por 10 minutos

En la Figura 12, se observa para los explantes no promisorios un crecimiento exponencial desde el día 3 al 10 y una disminución de los cultivos con esta característica a partir del día 14 al 17, con un incremento de 7 cultivos no promisorios el día 21.

\section{Efectos de la aplicación de $\mathrm{NaClO}$ 2\% durante 15 minutos}

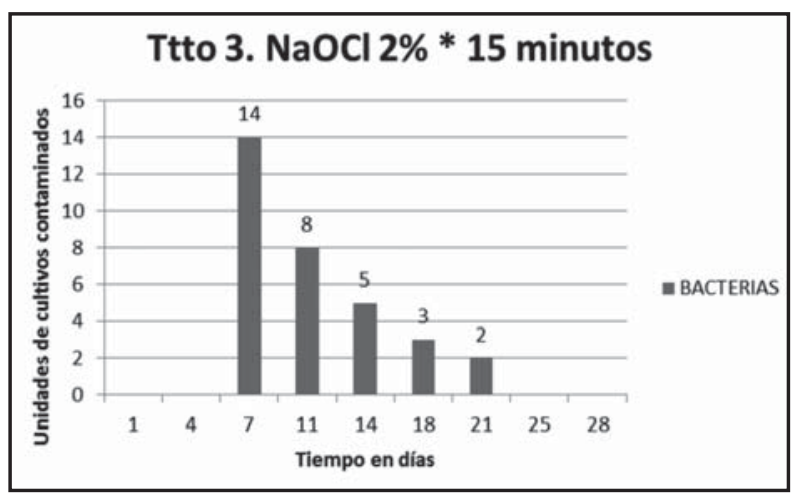

Figura 13 Análisis comparativo entre el protocolo de desinfección y la variable contaminación con el tratamiento $\mathrm{NaClO} 2 \%$ por 15 minutos
En la aplicación del $\mathrm{NaClO}$ al 2\% durante $15 \mathrm{mi}$ nutos (Figura 13), la contaminación se presenta en 14 de los segmentos nodales, a partir del séptimo día después de la siembra en el cultivo in vitro. Esta contaminación disminuye al igual que en los tratamientos 1 y 2 con el paso de los días. Este resultado concuerda con lo reportado por $\mathrm{Ra}$ mírez et al. (2002), quienes obtuvieron la mayor contaminación en los primeros siete días a partir de la siembra in vitro. Estos datos difieren de los resultados reportados por Marulanda et al. (2005), y Borges et al. (2004), quienes con este mismo tratamiento obtuvieron el $80.5 \%$ y el $25 \%$ de los explantes contaminados respectivamente.

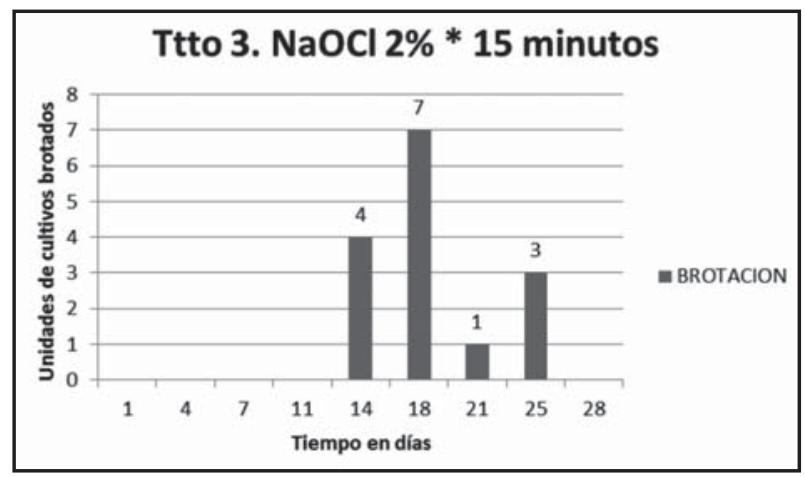

Figura 14 Análisis comparativo entre el protocolo de desinfección y la variable brotación con el tratamiento $\mathrm{NaClO} 2 \%$ por 15 minutos

La Figura 14 , expresa que a mayor tiempo se presentó mayor brotación, obteniendo 15 cultivos a partir del día 14 al 25 después de la siembra en el cultivo in vitro. El día 18 produjo el mayor número de cultivos brotados.

Como se puede apreciar en el tratamiento con $\mathrm{Na}$ $\mathrm{ClO}$ al 2\% durante 5, 10 y 15 minutos de aplicación, a medida que transcurre el tiempo del cultivo in vitro, disminuye la contaminación y aumenta la brotación de los explantes. Este comportamiento puede atribuirse a que la exposición a una concentración media de $\mathrm{NaClO}$ en un mayor tiempo podría activar la diferenciación celular de las yemas nodales y lograr una desinfección adecuada. Bajo estas condiciones los explantes sufren un menor daño 
fitotóxico en sus tejidos, evitando así su oxidación y facilitándose una regeneración in vitro más rápida y eficiente, lo cual concuerda con los resultados encontrados por Marulanda et al. (2005) en donde la mayor brotación se logró con el $\mathrm{NaClO}$ al $2 \%$ en un mayor tiempo de exposición (10 min). Sin embargo, Borges et al. (2004) lograron la mejor brotación con la doble desinfección de explantes primarios con $\mathrm{NaClO}$ al $2 \%$ por 5 min., al igual que Freire et al., (2011) quienes obtuvieron $95.81 \%$ de brotación aplicando la desinfección de las yemas axilares con $\mathrm{NaClO}$ al $1 \%$ durante 5 minutos.

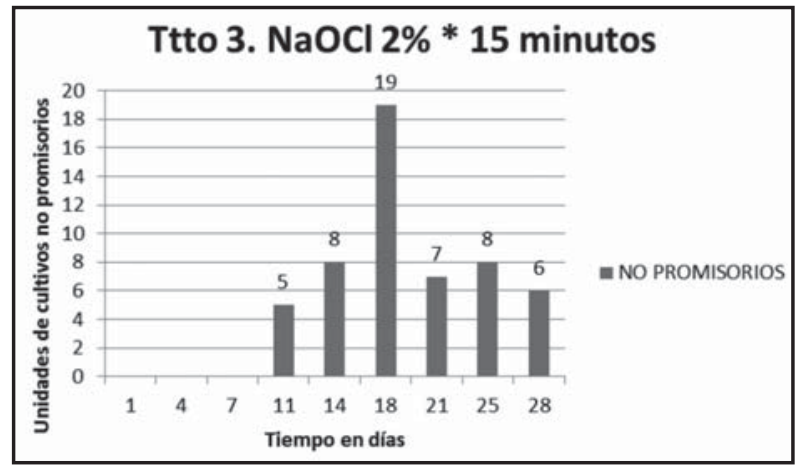

Figura 15 Análisis comparativo entre el protocolo de desinfección y la variable segmentos nodales no promisorios con el tratamiento $\mathrm{NaClO} 2 \%$ por 15 minutos

Para los explantes no promisorios se observó un aumento de cultivos con esta característica entre los días 11 al 18, siendo este último día el más representativo con 19 segmentos nodales no promisorios. Hay una disminución proporcional al aumentar el tiempo de exposición del cultivo a partir del día 21.

Con base en los resultados se observa que una concentración del $\mathrm{NaClO}$ del $2 \%$ por 15 minutos, es más efectivo que someter explantes a igual concentración por menor tiempo. Esto ha sido corroborado por Lin, Kalpana, Chang \& Lin (2007) quienes obtuvieron su mejor brotación y desinfección con la aplicación del $\mathrm{NaClO}$ al $2 \%$ durante 30 minutos en yemas de Bambusa oldhamii; y por Pedroza \& Bejarano (2008) en la desinfección de láminas foliares de Puya santossi, los cuales obtuvieron el mejor resultado con $\mathrm{NaClO}$ al $1 \%$ durante 10 minutos. Estos resultados son similares a los hallados por Borges, Estrada, Pérez \& Meneses, (2009) en segmentos uninodales de ñame, donde el mejor porcentaje de desinfección se obtuvo con el $\mathrm{NaClO}$ al $1.5 \%$ durante 30 min. Además coincide con los resultados reportados por Ramírez et al. (2002) en guanábano donde la mejor desinfección se logró con $\mathrm{NaClO}$ al 1\% por 10 min.

Los resultados obtenidos pueden explicarse en razón de que el hipoclorito de sodio tiene mayor oportunidad para llegar al tejido vegetal y hacer efectiva la eliminación de los microorganismos endógenos, sin perjudicar los tejidos del explante, ya que el agente desinfectante disminuye los iones hidroxilo $(\mathrm{OH})$, mediante la formación de agua; además, reduce el $\mathrm{pH}$ estimulando la presencia de ácido hipocloroso que en contacto con materia orgánica actúa como solvente y libera cloro que se combina con el grupo amino de las proteínas formando cloroaminas. El ácido hipocloroso y los iones hipoclorito $\left(\mathrm{OCl}^{-1}\right)$ llevan a la degradación e hidrólisis de los aminoácidos (Estrela et al., 2002), disminuyendo la tensión superficial de la membrana celular de las bacterias y permitiendo la lisis del microorganismo (Sánchez \& Sáenz, 2005). En este sentido, el hipoclorito tiene como mecanismo de acción sobre los microorganismos, la inhibición de las reacciones enzimáticas y desnaturalización de las proteínas (Sánchez \& Sáenz, 2005); este compuesto actúa como un solvente de materia orgánica, especialmente de ácidos grasos, a quienes transforma en sales de ácidos grasos (jabones) y glicerol, reduciendo la tensión superficial de la solución remanente. Además, el hipoclorito de sodio neutraliza los aminoácidos, formando agua y sales.

Análisis del tratamiento de $\mathrm{NACIO} 3 \%$ en relación con el tiempo de exposición de los explantes

Se realizó el análisis del comportamiento de los explantes en el tratamiento NACIO $3 \%$ de acuerdo con el tiempo de exposición de 5, 10 y 15 minutos, y durante los días del experimento en cuanto a su efecto de desinfección, brotación y segmentos nodales no promisorios. A continuación se presentan los resultados encontrados: 


\section{Efectos de la aplicación de $\mathrm{NaClO}$ $3 \%$ durante 5 minutos}

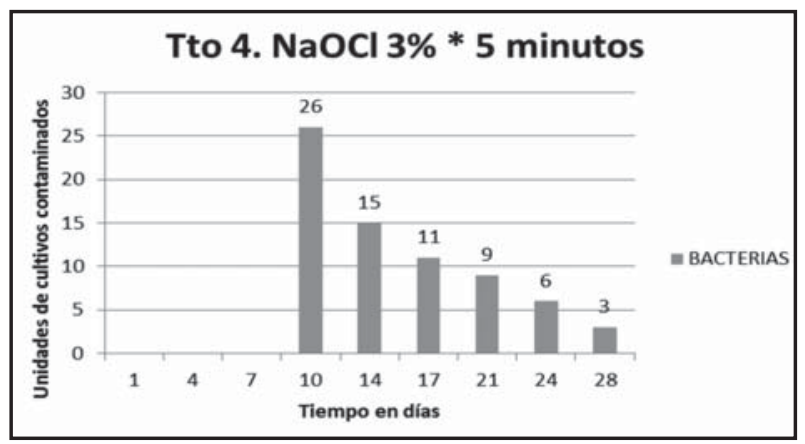

Figura 16. Análisis comparativo entre el protocolo de desinfección y la variable contaminación con el tratamiento $\mathrm{NaClO} 3 \%$ por 5 minutos

En la aplicación del $\mathrm{NaClO}$ al 3\% durante 5 minutos (Figura 16), la mayor contaminación se presenta en el día 10 a partir de la siembra en el cultivo in vitro en 26 de los segmentos nodales. Posteriormente la contaminación disminuye entre los días 10 y 28.

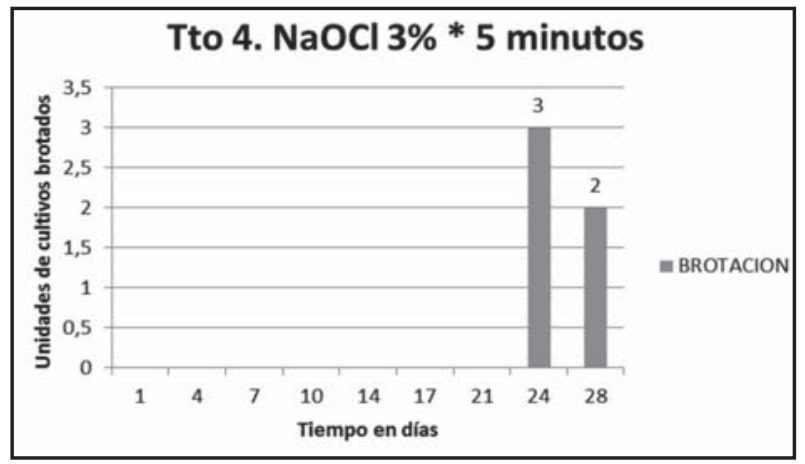

Figura 17. Análisis comparativo entre el protocolo de desinfección y la variable brotación con el tratamiento $\mathrm{NaClO} 3 \%$ por 5 minutos

En la Figura 17, se observa un bajo índice de brotación en este tratamiento con un total de 5 cultivos que se generaron entre el día 24 y 28 después de la siembra in vitro, indicando que una concentración alta con menor tiempo de exposición afecta el desarrollo diferencial de las células, impidiendo la brotación de los segmentos nodales de Guadua angustifolia.

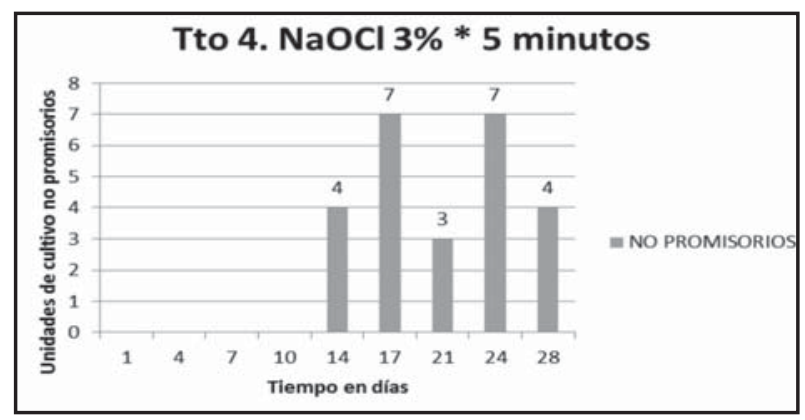

Figura 18. Análisis comparativo entre el protocolo de desinfección y la variable segmentos nodales no promisorios con el tratamiento $\mathrm{NaClO} 3 \%$ por 5 minutos

Para los explantes no promisorios (Figura 18), se observa un incremento de 11 explantes entre el día 14 y 17, disminuyendo al día 21. Posteriormente, se aprecia un aumento en el día 24 de 7 nuevos explantes, disminuyendo de nuevo al día 28.

\section{Efectos de la aplicación de $\mathrm{NaClO}$ al 3\% durante 10 minutos}

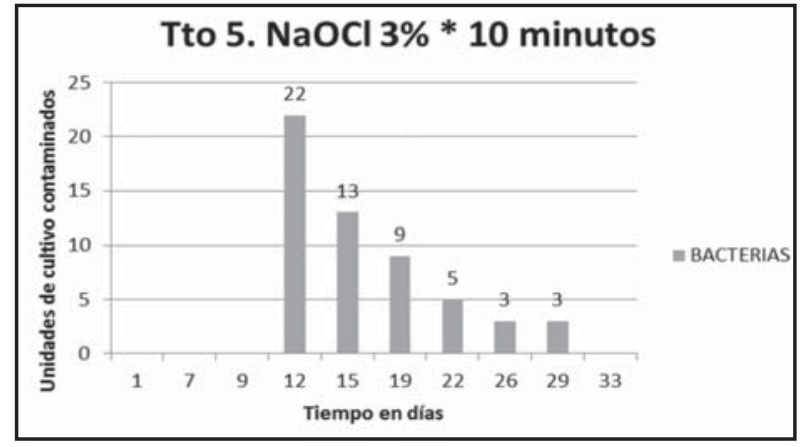

Figura 19. Análisis comparativo entre el protocolo de desinfección y la variable contaminación el tratamiento $\mathrm{NaClO} 3 \%$ por 10 minutos

En la aplicación del $\mathrm{NaClO}$ al 3\% durante $10 \mathrm{mi}-$ nutos, la mayor contaminación se presenta en el día 12 a partir de la siembra en el cultivo in vitro en 22 de los segmentos nodales sembrados. Esta contaminación disminuye progresivamente a partir del día 15 al 33, tal como se muestra en la Figura 19. 


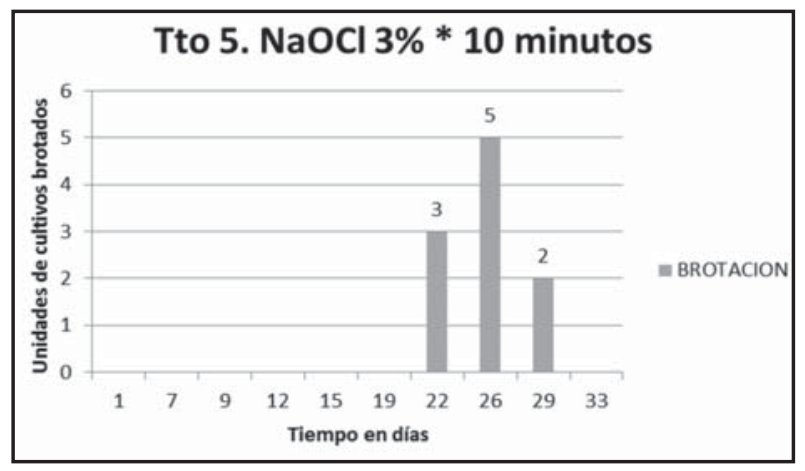

Figura 20. Análisis comparativo entre el protocolo de desinfección y la variable brotación el tratamiento $\mathrm{NaClO} 3 \%$ por 10 minutos)

En la Figura 20, se aprecia que se presentó una brotación de 10 cultivos entre el día 22 y 29 después de la siembra in vitro. Siendo el día 26 el más representativo en este tratamiento con 5 generaciones de brotes de Guadua angustifolia.

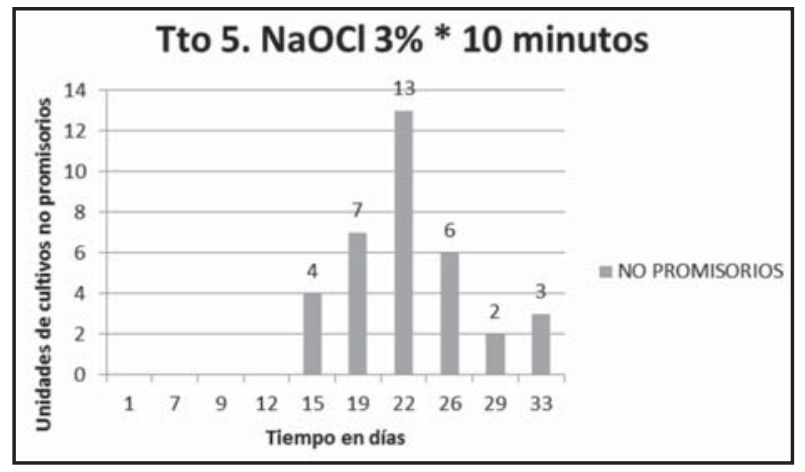

Figura 21. Análisis comparativo entre el protocolo de desinfección y la variable segmentos nodales no promisorios el tratamiento $\mathrm{NaClO} 3 \%$ por 10 minutos

Para los explantes no promisorios, se observa un aumento entre el día 15 y 22, con 24 explantes, siendo el día 22 después de la siembra in vitro el más representativo con 13 segmentos nodales con esta característica, disminuyendo su aparición entre el día 26 y 33, lo anteriormente expuesto, se muestra en la Figura 21.

\section{Efectos de la aplicación de $\mathrm{NaClO}$ al $3 \%$ durante 15 minutos}

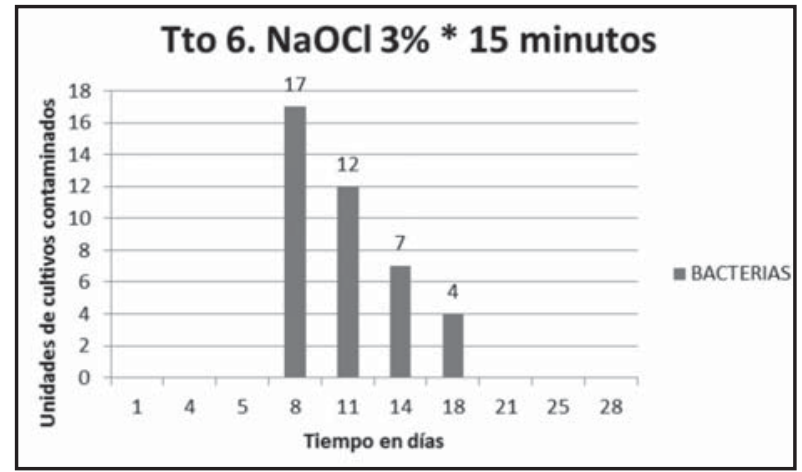

Figura 22. Análisis comparativo entre el protocolo de desinfección y la variable contaminación el tratamiento $\mathrm{NaClO} 3 \%$ por 15 minutos

En la aplicación del $\mathrm{NaClO}$ al 3\% durante $15 \mathrm{mi}-$ nutos (Figura 22), la mayor contaminación se presentó el día 8 a partir de la siembra en el cultivo in vitro en 17 explantes. Los mayores índices de contaminación se presentan entre los días 8 y 14, disminuyendo progresivamente con el tiempo.

De acuerdo con los resultados obtenidos en tratamientos con concentraciones medias y mayor tiempo de exposición, como el caso del tratamiento 3, $\mathrm{NaClO}$ al $2 \%$ por 15 minutos, se presentó una mejor desinfección y brotación. Sánchez \& Saens, (2005) indican que existe una estrecha correlación entre la concentración del agente desinfectante y el tiempo necesario para eliminar una determinada fracción de la población bacteriana, si se modifica la concentración se provocan cambios en el tiempo para lograr un mismo efecto.

Refiriéndose al tiempo, (Sánchez \& Sàenz, 2005) explican que no todas las bacterias mueren simultáneamente, ni siquiera cuando se aplica un exceso del agente desinfectante (Sánchez \& Sáenz, 2005). De ahí que no sea conveniente la aplicación 
del $\mathrm{NaClO}$ en una concentración alta por un menor tiempo de acción. Según los resultados encontrados en este estudio la concentración del hipoclorito de sodio al $3 \%$, no permite la adecuada desinfección de los explantes, ni la generación de la brotación de los segmentos nodales de $G$. angustifolia, al parecer el mecanismo de acción del $\mathrm{NaClO}$ y del alcohol, destruye los tejidos meristemáticos, generando un aumento en los explantes no promisorios.

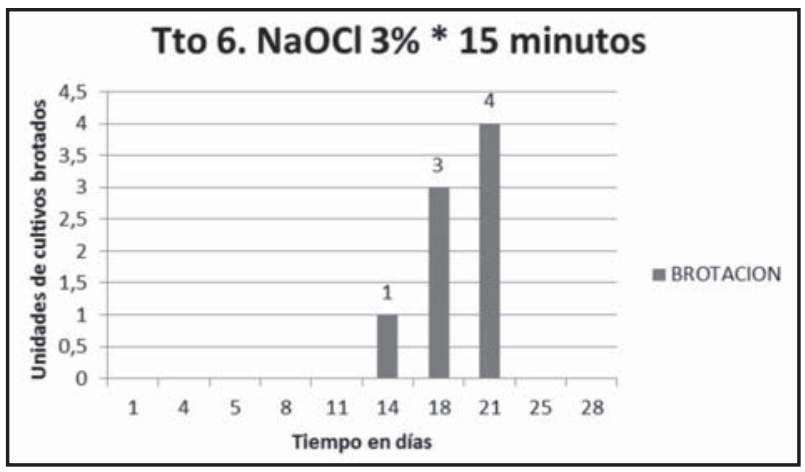

Figura 23. Análisis comparativo entre el protocolo de desinfección y la variable brotación el tratamiento $\mathrm{NaClO} 3 \%$ por 15 minutos

Para la variable brotación (Figura 23), se encontraron con este tratamiento 8 cultivos con generación de brotes entre el día 14 y 21, siendo este último día el de mayor brotación después de la siembra in vitro con 4 explantes brotados.

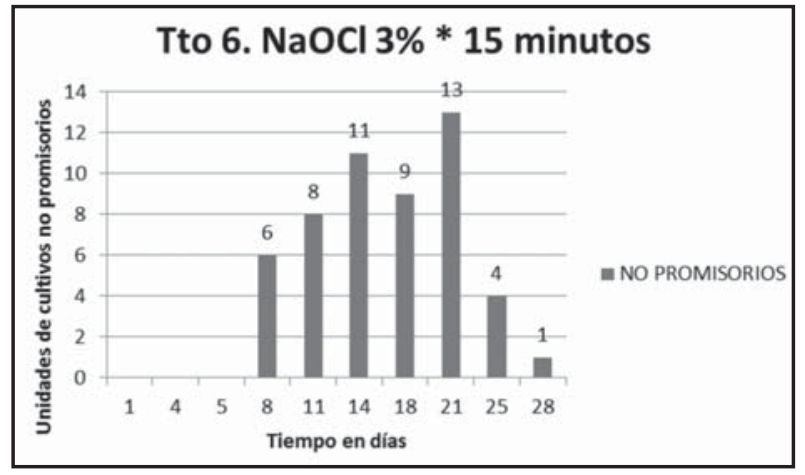

Figura 24. Análisis comparativo entre el protocolo de desinfección y la variable segmentos nodales no promisorios el tratamiento $\mathrm{NaClO} 3 \%$ por 15 minutos
Para los explantes no promisorios (Figura 24), se observó un aumento entre el día 8 a 21 . Posteriormente, disminuye el número de explantes no promisorios.

Una vez finalizado el análisis de las variables y de acuerdo con los resultados presentados para las concentraciones de $\mathrm{NaClO}$ al $2 \%$ y $\mathrm{NaClO}$ al $3 \%$ durante los diferentes tiempos de aplicación de 5,10 y 15 minutos respectivamente, sobre las unidades de cultivos contaminados, unidades de explantes brotados y segmentos nodales no promisorios, se presentan diferencias que pueden deberse a factores como la procedencia de los explantes y a los tratamientos de prevención utilizados: calidad del agua, aplicación de productos fungistáticos y/o bacteriostáticos, el corte de los explantes y herramientas empleadas (Sánchez \& Sáenz, 2005), así como también la predesinfección a la cual es sometido el explante.

El cultivo, el suelo, el clima donde las plantas crecen, y muchos otros aspectos bioclimáticos afectan de manera diferencial las condiciones del cultivo in vitro. Cualquier cambio en las concentraciones y los tiempos de exposición de los productos empleados en la predesinfección y en la desinfección hace que varien las condiciones del cultivo. Esto concuerda con lo citado por Borges et al., (2004), quien menciona la dificultad de encontrar una microporpagación eficiente para la Guadua angustifolia, teniendo en cuenta que los principales inconvenientes son, la contaminación microbiana endógena, la necrosis apical, la hiperhidricidad, la oxidación fenólica, el enraizamiento, la disponibilidad y respuesta estacional de los explantes, y la supervivencia ex vitro, además de la edad y estado del desarrollo de la planta madre.

Es importante resaltar que la aplicación del $\mathrm{NaClO}$ en concentraciones bajas durante mayor tiempo de exposición, permite un mejor desarrollo celular de los explantes, mientras que una concentración alta a un menor tiempo de exposición impide el 
adecuado desarrollo de los segmentos nodales de guadua. Esto puede deberse a que el hipoclorito de sodio afecta la permeabilidad celular del microorganismo y de las células vegetales, impidiendo el adecuado desarrollo celular de las células meristemáticas y por lo tanto no genera la brotación del segmento nodal. Según lo citado por Borges, et al., (2004), la acumulación de sustancias fenólicas liberadas por el tejido vegetal en el medio de cultivo, son con frecuencia inhibidores del crecimiento y constituyen uno de los problemas más frecuentes asociados con la propagación clonal, ya que alteran y deterioran la composición química del medio de cultivo, causando progresivamente la muerte del material vegetal.

Además como se mencionó anteriormente, cada cultivo tiene características independientes, como el corte, el estado del segmento nodal, la planta madre de la cual fue extraído, particularidades que hacen que cada cultivo sea una repetición de la investigación. La G. angustifolia, es una especie leñosa que reporta altos índices de contaminación y por lo tanto, requiere de unos pretratamientos y tratamientos más agresivos; en este caso, los segmentos nodales fueron prelavados para hacer un arrastre de macromoléculas en su exterior y sumergidos en alcohol al $70 \%$ durante 2 minutos, lo que también ayuda a romper la tensión superficial de la membrana celular de los microorganismos coadyuvando al hipoclorito de sodio a eliminar los agentes microbianos que impiden el adecuado establecimiento del cultivo in vitro de Guadua angustifolia, pero que debido a su compleja fisiología no fueron suficientes estos procedimientos, ni la desinfección con $\mathrm{NaClO}$.

A través de la observación de los cultivos de los segmentos nodales de G. angustifolia, se evidenció la presencia de bacterias como fuente contaminante a los 3 días. De acuerdo con Sánchez \& Sáenz, (2005), no todas las bacterias mueren simultáneamente en el momento de la desinfección, es por ello que según estos resultados, a medida que transcurre el tiempo prevalece el crecimiento bacteriano en el cultivo in vitro. Es de resaltar que no se presentó contaminación por hongos, aunque no fue un objetivo de este estudio, se puede inferir que las prácticas fitosanitarias aplicadas a las plantas madre en el invernadero, como la continua fumigación con productos fungistáticos y el riego con agua destilada, contribuyeron en buena medida a que no se hayan presentado hongos en el cultivo in vitro.

\section{Conclusiones}

El tratamiento con el cual se logró la mejor desinfección y brotación de los segmentos nodales de Guadua angustifolia se obtuvo con la aplicación del $\mathrm{NaClO}$ al $2 \%$ durante 15 minutos.

El tratamiento que generó menor resultado con respecto a la desinfección y brotación de los explantes fue el $\mathrm{NaClO}$ al $3 \%$ por 5 minutos.

Cuando se aumenta el tiempo de exposición al agente desinfectante, se disminuye el porcentaje de contaminación bacteriana, reflejándose un mayor efecto bactericida del $\mathrm{NaClO}$ en los segmentos nodales de Guadua angustifolia.

El uso del hipoclorito de sodio, es una alternativa para la desinfección del material vegetal en las concentraciones y tiempos de exposición adecuados.

Con los resultados obtenidos se confirma que son necesarios protocolos eficientes de micropropagación, debido a la complejidad del establecimiento en el cultivo in vitro de Guadua angustifolia.

\section{Agradecimientos}

\section{Corporación Autónoma Regional del Quindío}

Centra Nacional para el Estudio del Bambú - Guadua

Universidad Nacional Abierta y a Distancia, Escuela de Ciencias Agrícolas, Pecuarias y del Medio Ambiente. 


\section{Literatura citada}

1. Borges, M., Estrada, E., Pérez, I. \& Meneses, S. (2009). Uso de distintos tratamientos de desinfección en el cultivo in vitro de Dioscorea alata L. clon caraqueño. Centro de estudios de biotecnología vegetal. Facultad de ciencias agrícolas, Universidad de Granma, Bayamo 85 100. Cuba.

2. Borges, M., Ros, C., Castellanos \& Velásquez, R. (2004). Efecto de diferente métodos de desinfección en el establecimiento in vitro de Guadua angustifolia Kunth. Biotecnología vegetal Vol. 4 № 4: 237-242. Cuba.

3. Cruz, M., García, Y., Sánchez, C., Alvarado, Y., Acosta, M., Roque, B., Leiva, M. \& Freire, M. (2007). Identificación y control de Bacillus sp., contaminante del establecimiento in vitro de Guadua angustifolia Kunth. Biotecnología vegetal Vol. 7, № 1:9-13. Cuba

4. Estrela, C., Barbin, E. L., Spanó, J. C., Marchesan, M. A. \& Pécora, J. D. (2002). Mechanism of action of sodium hypochlorite. Braz Dent J. 13(2):113-7. 2. Recuperado de: http://www.forp.usp.br/bdj/bdj13(2)/v13n2a07/ v13n2a07.html

5. Fonturbel, F. Los vitropatógenos: consideraciones generales, detención y eliminación. Revista Biología.org, Vol.6. Recuperado de: http://www.biologia.org/revista/ numero6/vitropatogenos.html.

6. Freire, M., García, Y., Hurtado, O., León, M., Fajardo, L., Cruz, M., Sánchez, C., Alvarado, Y., Acosta, M., Tejada, M., Roque, B. \& Leiva, M. (2011). Combinación de técnicas biotecnológicas y tradicionales para la propagación de diferentes especies de bambú. Biotecnología vegetal Vol. 11, № 3:163 -168. Cuba.

7. Giraldo, E. \& Sabogal, A. (2007). Una alternativa sostenible: La Guadua técnicas de cultivo y manejo. Corporación Autónoma Regional del Quindío. 3 Ed. Armenia, Colombia.

8. Jiménez, V., Castillo, J., Tavares, E., Guevara, E., \& Montie, M. (2006). In vitro propagation of the neotropical giant bamboo, Guadua angustifolia Kunth, through axillary shoot proliferation. Plant cell tiss. Org. Cult. 86: 389 - 395.
9. Lárraga, N. (2011). Propagación in vitro y convencional de tres especies de Bambú. Puebla, México, 8-12 p. Tesis. Maestro en Ciencias. Colegio de Postgraduados. Posgrado en estrategias para el desarrollo agrícola regional.

10. Leifert, C., Ritchie, J. \& Waites, W. (1991). Contaminants of plant tissue and cell cultures. World Journal of Microbiology and Biotechnology. Oxford. Estados Unidos. $452-469$ p.

11. Lin, S., Kalpana, K. \&, Chang, W. (2007). Improving multiple shoot proliferation in bamboo mosaic virus - free Bambusa oldhamii Munro propagation by liquid culture. Hortscience 42 (5): 1243 - 1246 p. Taiwan, China.

12. Marulanda, M., Gutiérrez, L., Uribe, M. \& Márquez, M. (2005). Micropropagación de Guadua angustifolia. Biotecnología vegetal. Vol. 6 № 2. VII Simposio Internacional. Recuperado de: http://revista.ibp. co.cu/component/docman/doc_download/192-b

13. Pedroza, J. \& Bejarano, A. (2008). Propagación vegetativa in vitro de Puya santossi. Revista Colombiana de biotecnología. Vol. X №1: 36 - 48 p. Bogotá.

14. Ramírez, L., Castaño, S. \& López, R. (2009). Identificación de bacterias que afectan el establecimiento in vitro de segmentos nodales de Guadua angustifolia Kunth. Revista Investigaciones. Universidad del Quindío № 19: 151-158 p.

15. Ramírez, M., Urdaneta, A. \& León S. (2002). Establecimiento in vitro de explantes maduros del guanábano (Annona muricata L.) tratados con hipoclorito de sodio. Rev. Fac. Agron. Vol 19 № 1. Venezuela.

16. Roca, W. \& Mroginski, L. (1991). Cultivo de tejidos en la agricultura. Fundamentos y aplicaciones. Centro internacional de agricultura tropical. Cali, Colombia.

17. Sánchez, L. \& Sáenz, E. (2005). Antisépticos y desinfectantes. Dermatología Peruana. Volúmen 15. №2. 